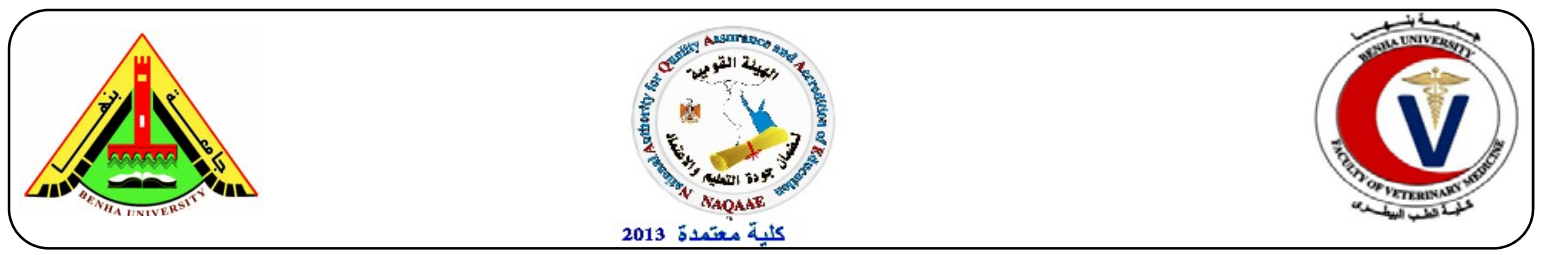

\title{
Bacteriological studies on some food borne bacteria isolated from Chicken meat and meat products in Kaliobia Governorate
}

\author{
Ashraf A. Abd El Tawab ${ }^{1}$, Ahmed, A. Maarouf ${ }^{2}$, Fatma I. El-Hofy ${ }^{1}$, Aya A. El-Said ${ }^{3}$ \\ ${ }^{1}$ Bacteriology, Immunology and Mycology Dept., Fac. Vet. Med. Benha Univ. ${ }^{2}$ Animal Health Research \\ institute "Benha branch". ${ }^{3}$ Veterinary practitioner.
}

\begin{abstract}
A B S T R A C T
A total of 125 random samples of fresh chicken, meat beef and beef meat products viz: minced meat, beef burger and sausage (25 for each), were collected from different shops in Benha city. The bacteriological examination of the samples indicated the isolation of food- borne pathogens from 79 positive samples $(63.2 \%)$ where, 113 isolates of food-borne pathogens were recovered from these samples, includes E. coli (46.9\%), Salmonellae (17.7\%) and S. aureus (35.4\%). They were isolated from minced meat samples $(28.3 \%)$ followed by sausage, chicken meat, beef meat and beef burger samples with an incidence of $21.2 \%, 19.4 \%, 18.6 \%$, and $12.4 \%$, respectively. E. coli strains (53) were isolated mostly from minced meat samples $(13=24.5 \%)$ followed by sausage $(12=22.6 \%)$, beef meat $(11=0$ $20.8 \%)$, chicken meat $(10=18.9 \%)$ and beef burger samples $(7=$ of $13.2 \%)$. Different serotypes of $E$. coli $\left(\mathrm{O}_{55}: \mathrm{H}_{7}, \mathrm{O}_{78}, \mathrm{O}_{111}: \mathrm{H}_{4}, \mathrm{O}_{26}: \mathrm{H}_{11}, \mathrm{O}_{119}: \mathrm{H}_{4}, \mathrm{O}_{125}: \mathrm{H}_{18}\right.$ beside 10 untyped strains) were recorded. All $E$. coli strains are sensitive to enrofloxacin, cefotaxime, gentamycin and norfloxacin. Salmonella strains (20) were isolated from minced meat $(7=35 \%)$, sausage and chicken meat $(4=20.0 \%$ for each one), beef meat $(3=15 \%)$ and beef burger samples $(2=10 \%)$. Three serotypes of Salmonellae were isolated as S. Typhimurium $(10=50 \%)$, S. Enteritidis $(8=40 \%)$ and S. Typhi $(2=10 \%)$ were recorded. The isolated Salmonella strains were highly sensitive to gentamycin, norfloxacin, enrofloxacin, ciprofloxacin and cefotaxime. S. aureus strains (40) were isolated from minced meat $(12=30 \%)$, sausage and chicken meat $(8=20 \%$ for each one), beef meat $(7=17.5 \%)$ and beef burger $(5=12.5 \%)$. All isolated strains were coagulase positive $S$. aureus. 6 strains out of 10 randomly examined $S$. aureus strains $(60.0 \%)$ were enterotoxigenic and classified according to type of toxin into (3A, 1B, 1C, 1A\&C). Moreover, the isolated $S$. aureus was highly sensitive to norfloxacin, enrofloxacin, gentamycin and ciprofloxacin.
\end{abstract}

Key words: chicken meat, E. coli, Salmonella, S. aureus.

(http://www.bvmj.bu.edu.eg)

(BVMJ-29(2): 47-59, 2015)

\section{INTRODUCTION}

$\mathrm{M}$ eat and meat products are the most palatable of highly nutritive value foods for human being as they are important sources for protein, fat, essential amino acids, minerals, vitamins and other nutrients (Biesalski, 2005). The intact tissues of healthy slaughtered birds and animals are mostly sterile but the meat may be contaminated during processing from the hands, worker's clothes, knives, the hide, the gut or from the environment resulting in an inferior or even unfit quality for human consumption. Contaminated chicken, beef and meat products may constitute a public health hazard (Ahmed and Ismail, 2010 and Datta et al., 2012). The most important bacterial pathogens in chicken meat, beef meat and meat products that are responsible for food-borne infections include E. coli, Salmonellae and coagulase positive S.aureus (Abdaslam et al., 2014, Ezzat et al., 2014 and Saif ,2015 ). Cattle is the most important reservoir for Enteropathogenic E. coli where carcass contamination mainly occurs during the hide removal process or evisceration and its 
presence in great number could easily give rise to public health hazards (Phillips et al., 2006). E.coli is commonly non-virulent but some strains have adopted pathogenic or toxigenic virulence factors that make them virulent to human and animals(Gi et al., 2009 and Datta et al., 2012). Infections with Salmonellae and coagulase positive $S$. aureus, are the causative agents of two thirds of food-borne disease outbreaks causing gastroenteritis and rarely acquired directly from raw meat but mostly occurs either due to excessive handling or contamination during or after cooking of meat and meat products (Busani et al., 2005). The emergence of antimicrobial resistance among E. coli, Salmonella and staphylococci strains of animal and poultry origin has important public health implications. Several studies showed that drug-resistant E. coli, Salmonella and Staphylococci infections in human were caused by strains from animals and poultry and that those infectious agents harbored the same mobile resistance genes as were found in diverse bacterial species from a variety of animal sources (Khan et al., 2009, Hammerum and Heuer, 2009 and Husain, 2010). As the level of contamination of both chicken meat and beef meat and its products with different food-borne pathogens constitutes serious problems for consumers, so, the present study was conducted to throw light over the bacterial status of chicken, beef meat and common meat products (minced meat, beef burger and sausage) at Kaliobia Governorate.

\section{MATERIAL AND METHODS}

\subsection{Samples collection}

A total of 125 random samples of fresh broiler chicken, meat beef and beef meat products viz: Minced meat, beef burger and sausage ( 25 for each), were collected from different shops at Benha city. Each examined sample was taken alone in sterile plastic bags, kept in icebox and transferred with minimum delay to the laboratory for bacteriological examination.

\subsection{Bacteriological examination}

Preparation of samples (APHA, 2001. Isolation and Identification of some foodborne pathogens:

\subsubsection{Isolation of E. coli strains:}

Isolation and identification morphologically by Gram stain, biochemically, serologically by slide agglutination test (using E. coli antisera "SEIKEN" Set 1, consists of 8 polyvalent and 430 (OK) antisera of Denka Seiken Co. LTD. Tokyo, Japan) and their In-Vitro antimicrobial Sensitivity using the disc and agar diffusion method according to Edwards and Ewing (1972), Koneman et al., (1997) and Quinn et al., (2002).

\subsubsection{Isolation of Salmonella strains:}

Isolation and identification of salmonella strains morphologically by Gram-stain, biochemically, serologically by slide and tube agglutination tests, (using antisera of Wellcome Diagnostic, Division of the Wellcome Foundation Limited Dartford, England) and their In-Vitro anti-microbial Sensitivity using the disc and agar diffusion method according to Kauffman (1973), Koneman et al., (1997), ISO 6579 (2002) and Quinn et al., (2002).

\subsubsection{Isolation of S. aureus strains:}

Isolation and identification of $S$. aureus morphologically by Gram stain and biochemical tests, their In-Vitro antimicrobial Sensitivity using the disc and agar diffusion method and detection of Enterotoxins producing isolates by SETRPLA technique according to Igarashi et al., (1986), Quinn et al., (2002) and Arora, (2003).

\section{RESULTS}

The bacteriological examination of studied samples revealed that, food- borne pathogens (E. coli, Salmonellae and S. aureus) were isolated from 79 positive samples $(63.2 \%)$, represented as 20 positive samples $(16.0 \% \& 25.3 \%)$ from minced 
meat samples followed by 17 sausages (13.6\% \& 21.5\%), 16 chicken meat (12.8\% \& $20.3 \%), 14$ beef meat $(11.2 \%$ \& $17.7 \%)$ and finally 12 beef burger $(9.6 \% \& 15.2 \%)$ samples (Table, 1). Most samples showed mixed isolates. Moreover, 113 isolates of food-borne pathogens were recovered from 125 samples, includes E. coli $(53=46.9 \%)$, Salmonellae $(20=17.7 \%)$ and $S$. aureus $(40=35.4 \%)$. They were isolated from minced meat samples $(32=28.3 \%)$, sausage $(24=21.2 \%)$, chicken meat $(22=19.4 \%)$, beef meat $(21=18.6 \%)$ and finally beef burger samples $(14=12.4 \%)$ as shown in Table (2).

The results of E. coli isolation (Table, 3) showed that, 53 strains were isolated mostly from minced meat samples $(13=24.5 \%)$ followed by sausage $(12=22.6 \%)$, beef meat $(11=20.8 \%)$, chicken meat $(10=18.9 \%)$ and beef burger samples $(7=13.2 \%)$. The results of serological identification of $E$. coli isolates Table (4) revealed that, out of 53 E. coli strains, 43 strains were typed as O55:H7 $\quad(13=24.5 \%), \quad$ O78 $\quad(5=9.4 \%)$, O111:H4 (8=15.1\%), O26:H11 (7=13.2\%), O119:H4 (2=3.8\%) and O125:H18 $(8=15.1 \%)$. While other 10 strains $(18.9 \%)$ were untyped by the available antisera. Moreover, the in- vitro sensitivity tests for the isolated E. Coli Table (5) showed that, the isolated $E$. coli were highly sensitive to enrofloxacin $(92.4 \%)$, cefotaxime $(90.5 \%)$, gentamycin $(86.8 \%)$ and norfloxacin (84.9\%). Meanwhile, they were moderately sensitive for ciprofloxacin (79.3\%) and doxycycline (75.5\%). Moreover, they were resistant for trimethoprim/ sulphamethoxazol (28.3\%), erythromycin $(26.4 \%)$, neomycin $(24.5 \%)$, pefloxacin $(11.3 \%)$, streptomycin $(7.5 \%)$ and ampicillin, amoxicillin, oxytetracycline with $(5.7 \%)$ for each. The results of Salmonella isolation (Table, 6) appeared that, a total of 20 Salmonella strains were isolated from minced meat $(7=35.0 \%)$, sausage and chicken meat $(4=20.0 \%$ for each one), beef meat $(3=15.0 \%)$ and beef burger samples $(2=10.0 \%)$. The results of serological identification of Salmonella Isolates, table (7) revealed that, 20 strains were serotyped as $S$. Typhimurium $(10=50.0 \%)$, S. Enteritidis $(8=40.0 \%)$ and S. Typhi $(2=10.0 \%)$. Moreover, The invitro sensitivity tests for the isolated Salmonella strains Table (8) showed that, the isolated Salmonella strains were highly sensitive to gentamycin, norfloxacin $(85.0 \%)$ for each,enrofloxacin, ciprofloxacin $(80.0 \%)$ for each and cefotaxime $(75.0 \%)$. Meanwhile, they were moderately sensitive for doxycycline $(65.0 \%)$ and weakly sensitive for trimethoprim/ sulphamethoxazol (55.0\%) and neomycin (50.0\%). Moreover, they were resistant for erythromycin $(40.0 \%)$, pefloxacin (30.0\%), ampicillin, amoxicillin, streptomycin with $(10.0 \%)$ for each and oxytetracycline $(5.0 \%)$. The results of $S$. aureus isolation (Table, 9 ) revealed that, 40 strains were isolated from minced meat $(12=30.0 \%)$, sausage and chicken meat $(8=20.0 \%$ for each one), beef meat $(7=17.5 \%)$ and beef burger $(5=12.5 \%)$. All isolated strains were coagulase positive $S$. aureus. The results of SET -RPLA test cleared that 6 strains out of 10 randomly examined strains $(60.0 \%)$ were enterotoxigenic and classified according to type of toxin into $(3 \mathrm{~A}, 1 \mathrm{~B}, 1 \mathrm{C}, 1 \mathrm{~A} \& \mathrm{C})$. Moreover, The in- vitro sensitivity tests for the isolated S.aureus Table (10) showed that, the isolated $S$. aureus were highly sensitive to norfloxacin $(95.0 \%)$, enrofloxacin $(92.5 \%)$, gentamycin $(90.0 \%)$, ciprofloxacin $(87.5 \%)$ and cefotaxime $(82.5 \%)$. Meanwhile, they were weakly sensitive to trimethoprim/ sulphamethoxazol (55.0\%), and pefloxacin $(52.5 \%)$. Moreover, they were resistant for neomycin $(42.5 \%)$, erythromycin $(37.5 \%)$, doxycycline $(32.5 \%)$, streptomycin $(10.0 \%)$ and ampicillin, amoxicillin, oxytetracycline with (7.5\%) for each. 
Table 1. Total number and Percentage of positive samples for pathogens isolation from studied samples:

\begin{tabular}{lccccc}
\hline \multirow{2}{*}{ Samples } & \multirow{2}{*}{$\begin{array}{c}\text { Number } \\
\text { sample }\end{array}$} & of & \multirow{2}{*}{$\begin{array}{c}\text { Number of } \\
\text { positive samples }\end{array}$} & \multicolumn{3}{c}{ Positive percentage } \\
\cline { 2 - 6 } Chicken meat & 25 & 16 & $\%^{1}$ & $\%^{2}$ & $\%^{3}$ \\
Beef Meat & 25 & 14 & 56 & 20.3 & 12.8 \\
Minced Meat & 25 & 20 & 80 & 17.7 & 11.2 \\
Beef Burger & 25 & 12 & 48 & 15.3 & 16.0 \\
Sausage & 25 & 17 & 68 & 21.5 & 13.6 \\
TOTAL & 125 & 79 & 63.2 & 100.0 & 63.2 \\
\hline
\end{tabular}

${ }^{1}$ Percentage in relation to total number of samples in each row. ${ }^{2}$ Percentage in relation to total number of positive samples (79). ${ }^{3}$ Percentage in relation to total number of collected samples (125)

\section{DISCUSSION}

Foodborne illnesses caused by E. coli, Salmonella species and $S$. aureus represented a major public health problem worldwide. These pathogens are transmitted mainly through consumption of contaminated food and the presence of these organisms in meat and raw meat products has relevant public health implications (Sousa, 2008). The results of Food- borne pathogens (E. coli, Salmonellae and $S$. aureus) isolation, (Table, 1) revealed that, 79 out of 125 samples were positive for isolation $(63.2 \%)$, represented as 20 positive samples $(16.0 \% \& 25.3 \%)$ from minced meat samples followed by 17 sausages $(13.6 \% \& 21.5 \%), 16$ chicken meat (12.8\% \& 20.3\%),14beef meat (11.2\% \& $17.7 \%)$ and finally 12 beef burger $(9.6 \% \& 15.2 \%)$ samples and most samples showed mixed isolates. This may be due to the combination of the low quality of beef carcass used, spreading of bacteria in meat by grinding, poor manufacturing processes, inadequate cleaning and disinfection of both equipment and surfaces or poor personal hygiene and use of untrained personnel. These results came in accordance with that obtained by Maarouf and Nassif 2008, Lamada et al., 2012 and Abdaslam et al., 2014. A total of 113 strains were recovered from 125 samples, includes E. coli $\quad(53=46.9 \%)$ Salmonellae $(20=17.7 \%)$ and $S$. aureus $(40=35.4 \%)$. They were isolated mostly from minced meat samples $\quad(32=28.3 \%)$, sausage $(24=21.2 \%)$, chicken meat $(22=19.4 \%)$, beef meat $(21=18.6 \%)$ and finally beef burger samples $(14=12.4 \%)$ as shown in Table (2). Nearly similar results were recorded by Maarouf and Nassif (2008), Lamada et al., (2012) and Abdaslam et al., (2014). These bacterial pathogens in meat and its products are of public health importance for consumers (Leloir et al., 2003 and Sousa, 2008).

The results of E. coli isolation (Table, 3) showed that 53 strains were isolated mostly from minced meat samples $(13=24.5 \%)$ followed by sausage $(12=22.6 \%)$, beef meat $(11=20.8 \%)$, chicken meat $(10=18.9 \%)$ and beef burger samples $(7=13.2 \%)$. Nearly similar results were obtained by Maarouf and Nassif (2008), Abdaslam et al., (2014), Abd El-Salam (2014), Ramadan (2015) and Saif (2015). The colonial appearance and the biochemical profile of E. coli isolated was similar to those previously reported such as the fermentation of certain sugars or enzymatic reaction (Quinn et al., 2002, and Ezzat et al., 2014). Regarding to, the serological identification of 53 isolated E. coli (Table, 4 ) showed that, 43 strains were typed as O55:H7 $\quad(13=24.5 \%), \quad$ O78 $\quad(5=9.4 \%)$, O111:H4 (8=15.1\%), O26:H11 (7=13.2\%), O119:H4 $(2=3.8 \%)$ and O125:H18 $(8=15.1 \%)$. While other 10 strains $(18.9 \%)$ were untyped by the available antisera. These results came in harmony with those of Kalchayanand et al., (2012), Windham 
Abd El Tawab et al. (2015)

Table (2): Incidence of food-borne pathogens in examined samples.

\begin{tabular}{|c|c|c|c|c|c|c|c|c|c|c|c|c|c|c|c|c|c|}
\hline \multirow{2}{*}{$\begin{array}{l}\text { Samples } \\
\text { Isolates }\end{array}$} & \multicolumn{3}{|c|}{ Chicken Meat } & \multicolumn{3}{|c|}{ Beef Meat } & \multicolumn{3}{|c|}{ Minced Meat } & \multicolumn{3}{|c|}{ Beef Burger } & \multicolumn{2}{|c|}{ Sausage } & \multicolumn{3}{|c|}{ TOTAL } \\
\hline & NO. & $\% *$ & $\% * *$ & NO. & $\% *$ & $\% * *$ & NO. & $\% *$ & $\% * *$ & NO. & $\% *$ & $\% * *$ & NO. & $\% *$ & $\% * *$ & NO. & $\% * *$ \\
\hline E.coli & 10 & 40 & 8.8 & 11 & 44 & 9.7 & 13 & 52.0 & 11.5 & 7 & 28.0 & 6.2 & 12 & 48 & 10.6 & 3 & 46.9 \\
\hline Salmonellae & 4 & 16 & 3.5 & 3 & 12 & 2.7 & 7 & 28 & 6.2 & 2 & 8 & 1.8 & 4 & 16 & 3.5 & 20 & 17.7 \\
\hline S. aureus & 8 & 32 & 7.1 & 7 & 28 & 6.2 & 12 & 48 & 10.6 & 5 & 20 & 4.4 & 8 & 32 & 7.1 & 0 & 35.4 \\
\hline TOTAL & 22 & 17.6 & 19.4 & 21 & 16.8 & 18.6 & 32 & 25.6 & 28.3 & 14 & 11.2 & 12.4 & 24 & 19.2 & 21.2 & 113 & 100 \\
\hline
\end{tabular}

* percentage in relation to total No. of each examined samples. ** Percentage in relation to total No. of 113 isolates.

Table (3): Incidence of E. coli strains isolated from examined samples ( $\mathrm{n}=25$, each sample):

\begin{tabular}{llll}
\hline Samples & NO. & $\begin{array}{c}\text { E. coli strains } \\
\% *\end{array}$ & \%** \\
\hline Chicken Meat & 10 & 40.0 & 18.9 \\
Beef Meat & 11 & 44.0 & 20.8 \\
Minced Meat & 13 & 52.0 & 24.5 \\
Beef Burger & 7 & 28.0 & 13.2 \\
Sausage & 12 & 48.0 & 22.6 \\
TOTAL & 53 & 42.4 & 100.0 \\
\hline
\end{tabular}

* Percentage in relation to total No. of each examined sample ( 25 \& 125 for total). $* *$ Percentage in relation to total No. of isolated E. coli (53). 
Table (4): Serological typing of E. coli strains isolated from different examined samples:

\begin{tabular}{|c|c|c|c|c|c|c|c|c|c|c|c|c|c|c|c|c|c|}
\hline \multirow{2}{*}{$\begin{array}{l}\text { Samples } \\
\text { E.coli serotypes }\end{array}$} & \multicolumn{3}{|c|}{ Chicken Meat } & \multicolumn{3}{|c|}{ Beef Meat } & \multicolumn{3}{|c|}{ Minced Meat } & \multicolumn{3}{|c|}{ Beef Burger } & \multicolumn{3}{|c|}{ Sausage } & \multicolumn{2}{|c|}{ TOTAL } \\
\hline & NO. & $\% *$ & $\% * *$ & NO. & $\% *$ & $\% * *$ & NO. & $\% *$ & $\% * *$ & NO. & $\% *$ & $\% * *$ & NO. & $\% *$ & $\% * *$ & NO. & $\% * *$ \\
\hline O55:H7 & 3 & 30 & 5.7 & 3 & 27.3 & 5.7 & 2 & 15.4 & 3.8 & 2 & 28.6 & 3.8 & 3 & 25 & 5.7 & 13 & 24.5 \\
\hline O78 & 0 & 0 & 0 & 2 & 18.2 & 3.8 & 2 & 15.4 & 3.8 & 0 & 0 & 0 & 1 & 8.3 & 1.9 & 5 & 9.4 \\
\hline O111:H4 & 2 & 20 & 3.8 & 1 & 9.1 & 1.9 & 2 & 15.4 & 3.8 & 1 & 14.3 & 1.9 & 2 & 16.7 & 3.8 & 8 & 15.1 \\
\hline O26:H11 & 1 & 10 & 1.9 & 2 & 18.2 & 3.8 & 2 & 15.4 & 3.8 & 1 & 14.3 & 1.9 & 1 & 8.3 & 1.9 & 7 & 13.2 \\
\hline O119:H4 & 0 & 0 & 0 & 1 & 9.1 & 1.9 & 1 & 7.6 & 1.9 & 0 & 0 & 0 & 0 & 0 & 0 & 2 & 3.8 \\
\hline O125:H18 & 1 & 10 & 1.9 & 1 & 9.1 & 1.9 & 2 & 15.4 & 3.8 & 2 & 28.6 & 3.8 & 2 & 16.7 & 3.8 & 8 & 15.1 \\
\hline Untyped & 3 & 30 & 5.7 & 1 & 9.1 & 1.9 & 2 & 15.4 & 3.8 & 1 & 14.3 & 1.9 & 3 & 25 & 5.7 & 10 & 18.9 \\
\hline TOTAL & 10 & 100 & 18.9 & 11 & 100 & 20.8 & 13 & 100 & 24.5 & 7 & 100 & 13.2 & 12 & 100 & 22.6 & 53 & 100 \\
\hline
\end{tabular}

* Percentage in relation to total No. of E. coli isolated in each sample. ** Percentage in relation to total No. of isolated E. coli (53).

Table 5. In-Vitro anti-microbial Sensitivity test for isolated E. coli

\begin{tabular}{|c|c|c|c|c|c|c|}
\hline Antibiotics & Disputant & highly sensitive & Moderately sensitive & $\begin{array}{l}\text { weakly sensitive } \\
\% \\
\end{array}$ & Total sensitive & Resistant \\
\hline Gentamycin & $10 \mathrm{mcg}$ & 77.4 & 9.4 & 7.5 & 86.8 & 5.7 \\
\hline Enrofloxacin & $5 \mathrm{mcg}$ & 81.1 & 11.3 & 7.5 & 92.4 & 3.8 \\
\hline Norfloxacin & $10 \mathrm{mcg}$ & 64.1 & 20.8 & 9.4 & 84.9 & 5.7 \\
\hline Trimethoprim/ Sulphamethoxazol & $(1.25 / 23.75) \mathrm{mcg}$ & 11.3 & 17.0 & 24.5 & 28.3 & 47.2 \\
\hline Doxycycline & $30 \mathrm{mcg}$ & 60.4 & 15.1 & 11.3 & 75.5 & 13.2 \\
\hline Ciprofloxacin & $5 \mathrm{mcg}$ & 62.3 & 17.0 & 9.4 & 79.3 & 11.3 \\
\hline Erythromycin & $15 \mathrm{mcg}$ & 11.3 & 15.1 & 20.8 & 26.4 & 52.8 \\
\hline Neomycin & $30 \mathrm{mcg}$ & 9.4 & 15.1 & 20.8 & 24.5 & 54.7 \\
\hline Pefloxacin & $5 \mathrm{mcg}$ & 3.8 & 7.5 & 15.1 & 11.3 & 73.6 \\
\hline Streptomycin & $10 \mathrm{mcg}$ & 1.9 & 5.7 & 17.0 & 7.5 & 75.5 \\
\hline Cefotaxime & $30 \mathrm{mcg}$ & 79.2 & 11.3 & 5.7 & 90.5 & 3.8 \\
\hline Ampicillin & $20 \mathrm{mcg}$ & 1.9 & 3.8 & 13.2 & 5.7 & 84.9 \\
\hline Oxytetracyclin & $30 \mathrm{mcg}$ & 1.9 & 3.8 & 11.3 & 5.7 & 83.0 \\
\hline Amoxicillin & $25 \mathrm{mcg}$ & 1.9 & 3.8 & 13.2 & 5.7 & 84.9 \\
\hline
\end{tabular}

Percentage in relation to total number of isolated E.coli (53) 
Table (6): Incidence of Salmonella strains isolated from examined samples:

\begin{tabular}{llcc}
\hline \multirow{2}{*}{ Samples } & \multicolumn{3}{c}{ Salmonella strains } \\
\cline { 2 - 4 } & NO. & $\%^{*}$ & 20.0 \\
Chicken Meat & 4 & 16.0 & 15.0 \\
Beef Meat & 3 & 12.0 & 35.0 \\
Minced Meat & 7 & 28.0 & 10.0 \\
Beef Burger & 2 & 8.0 & 20.0 \\
Sausage & 4 & 16.0 & 100.0 \\
TOTAL & 20 & 16.0 & \\
\hline
\end{tabular}

* Percentage in relation to total No. of each examined sample (25 \& 125 for total). ** Percentage in relation to total No. of isolated Salmonella strains (20).

Table (7): Serological typing of Salmonella strains isolated from different examined samples:

\begin{tabular}{|c|c|c|c|c|c|c|c|c|c|c|c|c|c|c|c|c|c|}
\hline \multirow{2}{*}{$\begin{array}{l}\text { Samples } \\
\text { Salmonella serotypes }\end{array}$} & \multicolumn{3}{|c|}{ Chicken Meat } & \multicolumn{3}{|c|}{ Beef Meat } & \multicolumn{3}{|c|}{ Minced Meat } & \multicolumn{3}{|c|}{ Beef Burger } & \multicolumn{3}{|c|}{ Sausage } & \multicolumn{2}{|c|}{ TOTAL } \\
\hline & NO. & $\% *$ & $\% * *$ & NO. & $\% *$ & $\% * *$ & NO. & $\% *$ & $\% * *$ & NO. & $\% *$ & $\% * *$ & NO. & $\% *$ & $\% * *$ & NO. & $\% * *$ \\
\hline S.Typhi & 1 & 25 & 5 & 2 & 66.7 & 10 & 4 & 57.1 & 20 & 1 & 50 & 5 & 2 & 50 & 10 & 10 & 50 \\
\hline S. Enteritidis & 3 & 75 & 15 & 1 & 33.3 & 5 & 2 & 28.6 & 10 & 1 & 50 & 5 & 1 & 25 & 5 & 8 & 40 \\
\hline S. Typhi & 0 & 0.0 & 0.0 & 0 & 0.0 & 0.0 & 1 & 14.3 & 5 & 0 & 0.0 & 0.0 & 1 & 25 & 5 & 2 & 10 \\
\hline TOTAL & 4 & 100 & 20 & 3 & 100 & 15 & 7 & 100 & 35 & 2 & 100 & 10 & 4 & 100 & 20 & 20 & 100 \\
\hline
\end{tabular}

* Percentage in relation to total No. of Salmonella isolated in each sample. ** Percentage in relation to total No. of isolated Salmonellae (20). 
Table (8): In-Vitro anti-microbial Sensitivity test for isolated Salmonella strains

\begin{tabular}{|c|c|c|c|c|c|c|}
\hline \multirow{2}{*}{ Antibiotics } & \multirow{2}{*}{ Disputant } & highly sensitive & Moderately sensitive & weakly sensitive & Total sensitive & Resistant \\
\hline & & \multicolumn{5}{|c|}{$\%$} \\
\hline Gentamycin & $10 \mathrm{mcg}$ & 70.0 & 15.0 & 10.0 & 85.0 & 5.0 \\
\hline Enrofloxacin & $5 \mathrm{mcg}$ & 65.0 & 15.0 & 15.0 & 80.0 & 5.0 \\
\hline Norfloxacin & $10 \mathrm{mcg}$ & 65.0 & 20.0 & 10.0 & 85.0 & 5.0 \\
\hline $\begin{array}{c}\text { Trimethoprim/ } \\
\text { Sulphamethoxazol }\end{array}$ & $(1.25 / 23.75) \mathrm{mcg}$ & 30.0 & 25.0 & 10.0 & 55.0 & 35.0 \\
\hline Doxycycline & $30 \mathrm{mcg}$ & 35 & 30.0 & 10.0 & 65.0 & 25.0 \\
\hline Ciprofloxacin & $5 \mathrm{mcg}$ & 55.0 & 25.0 & 10.0 & 80.0 & 10.0 \\
\hline Erythromycin & $15 \mathrm{mcg}$ & 15.0 & 25.0 & 15.0 & 40.0 & 45.0 \\
\hline Neomycin & $30 \mathrm{mcg}$ & 20.0 & 30.0 & 10.0 & 50.0 & 40.0 \\
\hline Pefloxacin & $5 \mathrm{mcg}$ & 15.0 & 15.0 & 15.0 & 30.0 & 55.0 \\
\hline Streptomycin & $10 \mathrm{mcg}$ & 5.0 & 5.0 & 15.0 & 10.0 & 75.0 \\
\hline Cefotaxime & $30 \mathrm{mcg}$ & 60.0 & 15.0 & 15.0 & 75.0 & 10.0 \\
\hline Ampicillin & $20 \mathrm{mcg}$ & 5.0 & 5.0 & 10.0 & 10.0 & 80.0 \\
\hline Oxytetracyclin & $30 \mathrm{mcg}$ & 0.0 & 5.0 & 10.0 & 5.0 & 85.0 \\
\hline Amoxicillin & $25 \mathrm{mcg}$ & 5.0 & 5.0 & 10.0 & 10.0 & 80.0 \\
\hline
\end{tabular}

Percentage in relation to total number of isolated Salmonella strains (20)

Table (9): Incidence of S. aureus strains isolated from examined samples:

\begin{tabular}{lccc}
\hline Samples & SO. aureus & \%* & \%** \\
\hline Chicken Meat & 8 & 32.0 & 20.0 \\
Beef Meat & 7 & 28.0 & 17.5 \\
Minced Meat & 12 & 30.0 & 30.0 \\
Beef Burger & 5 & 20.0 & 12.5 \\
Sausage & 8 & 32.0 & 20.0 \\
TOTAL & 40 & 32.0 & 100.0 \\
\hline
\end{tabular}

* Percentage in relation to total No. of each examined sample ( $25 \& 125$ for total). ** Percentage in relation to total No. of isolated S. aureus (40). 
Abd El Tawab et al. (2015)

Table (10): In-Vitro anti-microbial Sensitivity test for isolated S.aureus:

\begin{tabular}{|c|c|c|c|c|c|c|}
\hline Antibiotics & Disputant & $\begin{array}{l}\text { highly } \\
\text { sensitive }\end{array}$ & $\begin{array}{l}\text { Moderately } \\
\text { sensitive }\end{array}$ & $\begin{array}{l}\text { weakly } \\
\text { sensitive } \\
\%\end{array}$ & $\begin{array}{r}\text { Total } \\
\text { sensitive }\end{array}$ & Resistant \\
\hline Gentamycin & $10 \mathrm{mcg}$ & 75.0 & 15.0 & 5.0 & 90.0 & 5.0 \\
\hline Enrofloxacin & $5 \mathrm{mcg}$ & 72.5 & 20.0 & 2.5 & 92.5 & 5.0 \\
\hline Norfloxacin & $10 \mathrm{mcg}$ & 77.5 & 17.5 & 2.5 & 95.0 & 2.5 \\
\hline $\begin{array}{c}\text { Trimethoprim/ } \\
\text { Sulphamethoxazol }\end{array}$ & $\begin{array}{l}1.25 / 23.75 \\
\mathrm{mcg}\end{array}$ & 25.0 & 30.0 & 12.5 & 55.0 & 32.5 \\
\hline Doxycycline & $30 \mathrm{mcg}$ & 17.5 & 15.0 & 10.0 & 32.5 & 57.5 \\
\hline Ciprofloxacin & $5 \mathrm{mcg}$ & 70.0 & 17.5 & 0.0 & 87.5 & 12.5 \\
\hline Erythromycin & $15 \mathrm{mcg}$ & 17.5 & 20.0 & 12.5 & 37.5 & 50.0 \\
\hline Neomycin & $30 \mathrm{mcg}$ & 22.5 & 20.0 & 12.5 & 42.5 & 45.0 \\
\hline Pefloxacin & $5 \mathrm{mcg}$ & 25.0 & 27.5 & 10.0 & 52.5 & 37.5 \\
\hline Streptomycin & $10 \mathrm{mcg}$ & 2.5 & 7.5 & 12.5 & 10.0 & 77.5 \\
\hline Cefotaxime & $30 \mathrm{mcg}$ & 67.5 & 15.0 & 7.5 & 82.5 & 10.0 \\
\hline Ampicillin & $20 \mathrm{mcg}$ & 2.5 & 5.0 & 10.0 & 7.5 & 82.5 \\
\hline Oxytetracyclin & $30 \mathrm{mcg}$ & 2.5 & 5.0 & 7.5 & 7.5 & 85.0 \\
\hline Amoxicillin & $25 \mathrm{mcg}$ & 2.5 & 5.0 & 10.0 & 7.5 & 82.5 \\
\hline
\end{tabular}

Percentage in relation to total number of isolated S. aureus (40). 
et al, (2013) and Abd El-Salam (2014). These results coincided with the fact of Woody et al., (1998) who recorded that the same serogroups were Enteropathogenic E. coli and causing infantile enteritis, hemorrhagic colitis, hemorrhagic gastroenteritis and diarrheal illness in different settings. Moreover, the results of antibiotic sensitivity tests for the isolated $E$. coli Table (5) showed that, the isolated $E$. coli were highly sensitive to enrofloxacin, cefotaxime,

gentamycin and norfloxacin. Meanwhile, they were moderately sensitive for ciprofloxacin and doxycycline. Moreover, they were very high resistance to pefloxacin, streptomycin, ampicillin, amoxicillin and oxytetracycline. These results go in parallel with those obtained by Fazlina et al., (2012) and Zhao et al., (2012). Moreover, our results proved that multiple antibiotic resistances are widely spread among isolated strains of E. coli.

The results of Salmonella isolation (Table, 6) revealed that, a total of 20 Salmonella strains were isolated from examined samples where7 $(35.0 \%), 4(20.0 \%), 4$ $(20.0 \%), 3(15.0 \%)$ and $2(10.0 \%)$ were isolated from minced meat, chicken meat, sausage, beef meat and beef burger samples respectively. Nearly similar results were recorded by Phillips et al., (2006), Maarouf and Nassif (2008), Lamada et al.,2012, Abdaslam et al., (2014), Abd El-Salam (2014), Ramadan (2015) and Saif (2015). The colonial appearance and the biochemical profile of isolated Salmonella strains was similar to those previously reported by Kumar et al., (2010), Ozkalp (2012) and Abd El-Salam (2014). Regarding the serological identification of 20 isolated Salmonella strains (Table, 7) Showed that, S. Typhimurium was the predominant serotype isolated $(10=50.0 \%)$ followed by $S$. Enteritidis $(8=40.0 \%)$ and $S$. Typhi $(2=10.0 \%)$ which were from groups $\mathrm{B}$ and D. The majority of the Salmonella serotypes isolated from all the sources are known to be pathogenic to humans. Similar results were obtained by Phillips et al.
(2006), Maarouf and Nassif (2008), Dogru et al., (2010), Husain (2010), Edris et al, (2011), Ghozzi et al., (2012), Lamada et al., (2012), Abdaslam et al., (2014) and Ahmed and Shimamoto (2014) Referring to presence of S. Typhi and S. Enteritidis in meat and meat products indicates that the contamination is from human origin and may be the result of poor personal hygiene during handling and processing of food, whereas presence of $S$. Typhimurium indicates the contamination is from chicken and animal tissues sources (Abdaslam et al., 2014). The results of antibiotic sensitivity tests for the isolated Salmonella Strains. Table (8) showed that, the isolated Salmonella strains were highly sensitive to gentamycin, norfloxacin, enrofloxacin, ciprofloxacin and cefotaxime. Meanwhile, they were very high resistance for ampicillin, amoxicillin, streptomycin and oxytetracycline. These results go in parallel with those obtained by Zhao et al., (2008), Aslam et al., (2012), Fazlina et al., (2012) and Abd El-Salam (2014).

The results of $S$. aureus isolation (Table, 9) cleared that, 40 strains were isolated from minced meat $(12=30.0 \%)$, sausage and chicken meat ( $8=20.0 \%$ for each one), beef meat $(7=17.5 \%)$ and beef burger $(5=12.5 \%)$. These results were nearly similar to Aseel et al., 2010, Kanika et al., 2011, Goja et al., 2013, Jackson et al., 2013, Abdaslam et al.,2014 and Ezzat et al.,2014. The presence of $S$. aureus in meat and its products indicates poor hygiene of meat handlers as well as lack of sterilization of utensils and they grow without pronounced change in odour or taste in the products and producing heat stable enterotoxins which lead to food poisoning with severe diarrhoea and gastroenteritis among consumers (Plaatjies et al., 2004).

The colonial appearance and the biochemical profile of S.aureus isolated was similar to those previously reported such as the fermentation of certain sugars or enzymatic reaction as lipase, extracellular pigmentation production (Staphyloxathine) and Staphylocoagulase (Quinn et al., 2002, 
Shittu et al., 2006 , Chandrakanth et al., 2010 and Ezzat et al., 2014).Moreover, all isolated strains were coagulase positive $S$. aureus. Nearly similar results were obtained by Phillips et al., (2006), Maarouf and Nassif (2008), Chandrakanth et al., (2010) and Abdaslam et al., (2014). Six S. aureus strains out of 10 randomly examined ones $(60.0 \%)$ using the SET- RPLA test, were enterotoxigenic and classified according to type of toxin into $(3 \mathrm{~A}, 1 \mathrm{~B}, 1 \mathrm{C}$, $1 \mathrm{~A} \& \mathrm{C})$. This result nearly similar to that recorded by (Rosec et al, 1997, Abdaslam et al., 2014 and Ezzat et al., 2014) who found enterotoxin $\mathrm{A}, \mathrm{C}$ and $\mathrm{A} \& \mathrm{C}$ in chicken, beef meat and meat products. The in- vitro sensitivity tests for the isolated S.aureus Table (10) showed that, the isolated S.aureus were highly sensitive to norfloxacin, enrofloxacin, gentamycin, ciprofloxacin and cefotaxime. Meanwhile, they were highly resistant for ampicillin, amoxicillin, oxytetracycline and streptomycin. These results were agreed with (Datta et al., 2012, Abd El- Salam, 2014 and Ezzat et al., 2014).

Finally, our results proved that multiple antibiotic resistances are widely spread among isolated strains of E. coli, Salmonella and S.aureus. Moreover, our recorded results showed a high bacterial load beside a relatively high rate of pathogens, this may be due to mishandling and the negligence of hygienic aspects either at production levels where most workers did not have medical certificates or selling of meat with expired dates. Therefore, it was concluded that E. coli, Salmonellae and coagulase positive S. aureus are meat-borne pathogens of public health important.

\section{REFERENCES}

Abd El- Salam-Azza, S. 2014. Molecular detection of antimicrobial resistance for some food borne pathogens. Ph.D. Thesis (Bacteriology, Mycology and Immunology) Fac.Vet.Med, Zagazig Univ.
Abdaslam, S. A., Hassan, M. A., Kaheel, H. A., Abobaker, T. M., Alnourain, T. H., Hamdan, H. A., Gokul Shankar, S. Thambirajah, J. (2014): Isolation of Escherichia coli $\mathrm{O} 157$ and other food borne pathogens from meat products and their susceptibility to different antimicrobial agents. Current Research in Microbiology and Biotechnology, 2 (3): 391-397.

Ahmed, A.M. Ismail, T.H. 2010. Improvement of the quality and shelf-life of minced beef mixed with soyprotien by Sage (Saliva officinalis). African J. Food Science, 4:330-334.

Ahmed, A.M., Shimamoto, T. 2014. Isolation and molecular characterization of Salmonella enterica, Escherichia coli $\mathrm{O}_{157}: \mathrm{H}_{7}$ and Shigella spp. from meat and dairy products in Egypt. Int. J. Food Microbiol., 168-169.

APHA "American Public Health Association" 2001. Compendium of Methods for the Microbiological examination of Foods. $4^{\text {th }}$ Ed. F.P. Downes and K. Ito (editors), APHA. Washington D.C.

Arora, D.R. 2003. Text Book of Microbiology. $2^{\text {nd }}$ Edition (Cultural characteristics of Staphylococcus spp. 2012-2013), Publishing by Satish Kumar Jain for CBS publishers.

Aseel, M.H., Maysoon, S.A., Waffa, A.A. 2010. The isolation and identification of the important pathogenic bacteria from fresh meat. The Iraq J. for Vet.Med.,23(1):4450.

Aslam, M., Checkley, S., Avery, B., Chalmers, G., Bohaychuk, V., Gensler, G., ReidSmith, R., Boerlin, P. 2012. Phenotypic and genetic characterization of antimicrobial resistance in Salmonella serovars isolated from retail meats in Alberta, Canada. Food Microbiol., 32(1): 110117.

Biesalski, H.K. 2005. Meat as a component of a healthy diet. Are there any risks or benefits if meat is avoided in the diet. Meat Science J., 70: 509-524.

Busani, L., Cigliano, A., Tailoli, E. 2005. Prevalence of Salmonella enterica and Listeria monocytogenes contamination in food of animal origin in Italy. J. food prot., 68(8):1729-1733. 
Chandrakanth, K., Virupakshaiah, D.B.M., Gavimath, C.C., Udaykumar, M., Kangralkar, V.A. 2010. Comparative genomics of Staphylococcus aureus coagulase gene. Journal of Advanced Bioinformatics Applications and Research, 1(1): 31-36.

Datta,S., Akter, A., Shah, I.G., Fatema, K., Islam, T.H., Bandyopadhyay, A., Khan, Z.U.M. , Biswas, D. 2012. Microbiological Quality Assessment of Raw Meat and Meat Products and Antibiotic Susceptibility of Isolated Staphylococcus aureus. J. Agric. Food Anal. Bacteriol., 2: 187-195.

Dogru, A.K., Ayaz, N.D., Gencay, Y.E. 2010. Serotype identification and antimicrobial resistance profiles of Salmonella spp. isolated from chicken carcasses. Tropical Animal Health and Production, 42(5):893-897.

Edris, A.M., Shaltout, F.A., Salem, G.H., ElToukhy, E.I. 2011. Incidence and Isolation of Salmonellae from Some Meat Products. Food Science and Technology, 1:194-200.

Edward,P.R. , Ewing, W.H. 1972. Edwards and Ewing's identification of Enterobacteriacae, $3^{\text {rd }}$ Ed. Burgess, Minneapolis.

Ezzat, M., Shabana, I.I., Mohammed-Gihan, M.O., Abd El-Hak-Marwa 2014. Molecular characterization of pathogenic E. coli isolated from meat and their products. SCVMJ, 21(1):103-113.

Fazlina F., Al-Sultan, I.I., Jasbir, S.I. 2012. Antibiotic sensitivity of pathogenic bacteria isolated from beef samples obtained from Kota Bharu and its surrounding provinces. Journal of Advanced Medical Research, 2:8-11.

Ghozzi, A.I., Jaouani, A., Hammami, S., Martinez-Urtaza, J., Boudabous, A., Gtari, M. 2012. Molecular analysis and antimicrobial resistance of Salmonella isolates recovered from raw meat marketed in the area of Grand Tunis, Tunisia. Pathol. Biol. (Paris), 60(5):4954.

Gi, Y.L., Hye, I.J., In, G.H., Min, S.R. 2009. Prevalence and classification of pathogenic E. coli isolated from fresh beef, poultry and pork in Korea. International J. Food Microbiology, 134(3):196-200.
Goja, A.M., Ahmed, T.A.A., Saeed, S.A.M., Dirar, H. A. 2013. Isolation and Identification of Staphylococcus spp. in Fresh Beef. Pakistan J. Nutrition, 12(2):114-120.

Hammerum, A.M., Heuer, O.E. 2009. Human health hazards from antimicrobialresistant Escherichia coli of animal origin. Clin. Infect. Dis., 48:916-921.

Husain, A. 2010. Prevalence and antimicrobial resistance of Salmonella serovars isolated from poultry and meat in Hyderabad, Pakistan. Turk. Vet. Anim. Sci., 34(5):455-460.

Igarashi, H., Fujikawa, H., Shingaki, M., Bergdoll, M.S. 1986. Latex agglutination test for Staphylococcus Toxic Shock syndrome toxin 1, J. Clin. Microbiol., 23:516:521.

International Organization of Standardization "ISO" 2002. International Organization for Standardization. No.6579. Microbiology of food and animal feeding stuffs-Horizontal methods for detection of salmonella species.

Jackson, C.R., Davis, J.A., Barrett, J.B. 2013. Prevalence and characterization of Methicillin-Resistant Staphylococcus aureus isolates from retail meat and humans in Georgia. J. Clinic. Microbiol., 51(4):1199-1207.

Kalchayanand, N., Arthur, T.M., Bosilevac, J.M., Schmidt, J.W., Wang, R., Shackelford, S.D., Wheeler, T.L. 2012. Evaluation of commonly used antimicrobial interventions for fresh beef inoculated with Shiga toxin-producing Escherichia coli serotypes $\mathrm{O}_{26}, \mathrm{O}_{45}, \mathrm{O}_{103}$, $\mathrm{O}_{111}, \mathrm{O}_{121}, \mathrm{O}_{145}$ and $\mathrm{O}_{157}: \mathrm{H}_{7}$, J. Food Prot., 75(7):1207-1212.

Kanika, B., Xiaogang, W., Susan, D., Marcus, Z., Liziane, R., Yifan, Z. 2011. Methicillin- Resistant Staphylococcus aureus in Retail Meat, Detroit, Michigan, USA. Emerg. Infect. Dis., 17(6):1135-1137.

Kauffmann F. 1973. Serological diagnosis of salmonella species Kauffmann while Scheme. Copenhagen, Denmark. J. Acta. Path. Microbiol. Sci., 61:385.

Khan, E., Jabeen, K., Ejaz, M., Siddiqu, J., Shezad, M.F., Zafar, A. 2009. Trends in antimicrobial resistance in Shigella species in Karachi, Pakistan. J. Infection in Developing Countries, 3: 798-802. 
Konemann, E., Allen, S., Janda, W., Schreckenberger, C., Winn, W. (1997): Color Atlas and Textbook of Diagnostic Microbiology. Fifth Edition. Lippincott, Philadelphia, New York.

Kumar, R., Surendran, P.K., Thampuran, N. 2010. Evaluation of culture media for selective enrichment and isolation of Salmonella in seafood. J. AOAC Int., 93(5):1468-1471.

Lamada-Hanan, M., Nassif-Marionette, Z., Eleiwa-Nesreen, $\quad$ Z. 2012. Microbiological evaluation of some chicken meat and meat products. Egypt. J. Agric. Res., 90(1):279-293.

Leloir, Y., Baron, F., Gautier, M. 2003. Review: Staph.aureus and food poisoning. J. Genetics and Molecular Research, 2(1): 63-76.

Maarouf, A.A., Nassif-Marionette, Z. 2008. Bacteriological studies on frozen cow meat and some meat products at Benha city. J. Egypt. Vet. Med. Assoc., 68(1):129-141.

Ozkalp, B. 2012. Isolation and identification of Salmonella from different samples, Salmonella-A dangerous foodbome pathogen, Dr. Barakat, S.M.M. (Ed.), $\mathrm{http} / / / \mathrm{www}$.intechopen.com/books/Salm onella-a-dangerous-foodbomeathogen/isolation-and-identification-ofSalmonellas-from-different-samples.

Phillips, D., Jordan, D., Morris, S., Jenson, I., Sumner, J. 2006. A national survey of the microbiological quality of beef carcasses and frozen boneless beef in Australia. J. food prot., 69(5):1113-1117.

Plaatjies, Z., Lues, J., Buys, E. 2004. Staphylococcal growth in fresh vacuumpacked red meat at various storage conditions. $8^{\text {th }}$ World Congress on Environmental Health. Durban, South Africa.

Quinn, p., Markey, B., Carter, M., Donelly, W., Leonard, F. 2002. Veterinary microbiology and microbial disease. Black Well Science, chapters 26-36.

Ramadan, A.M. 2015. Contamination of meat products with human pathogens. M.V. Sc. Thesis (Meat hygiene), Fac. Vet. Med., Alex. Univ.
Rosec, J.P., Guiraud, J.P., Dalet, C., Richard, N. 1997. Enterotoxin production by Staphylococci isolated from foods in France. International J. Food Microbiology, 35(3):213-221.

Saif-Marwa, Z.M.A. 2015. Bacterial Status of Fresh Marketed chicken cuts. M.V.Sc. Thesis, Meat Hygiene, Fac.Vet.Med., Benha Univ.

Shittu, A., Lin, J., Morrison, D., Kolawole, D. 2006. Identification and molecular characterization of mannitol salt positive, coagulase-negative staphylococci from nasal samples of medical personnel and students. J. Med. Microbiol., 55(3):317324.

Sousa, C.P. 2008. The Impact of Food Manufacturing Practices on Food-borne Diseases. Brazilian Archives of Biology and Technology, 51(4),815-823.

Windham, W.R., Yoon, S.C., Ladely, S.R., Haley, J.A., Heitschmidt, J.W., Lawrence, K.C., Park, B., Narrang, N., Cray, W.C. 2013. Detection by hyperspectral imaging of shiga toxinproducing Escherichia coli serogroups $\mathrm{O}_{26}, \mathrm{O}_{45}, \mathrm{O}_{103}, \mathrm{O}_{111}, \mathrm{O}_{121}$ and $\mathrm{O}_{145}$ on rainbow agar. J. Food Prot., 76(7): 11291136.

Woody, J.M., John, A.S., Richard, A.W., Stephen, J.K. 1998. Comparison of the Difco E. coli rapid detection system and petriflim test kit-HEC for detection of Escherichia coli $\mathrm{O}_{157}: \mathrm{H}_{7}$ in fresh and frozen ground beef, J. Food Prot., 61:110-112.

Zhao, S., Blickenstaff, K., Bodeis-Jones, S., Gaines, S.A., Tong, E., McDermott, P.F. 2012. Comparison of the prevalence and antimicrobial resistances of Escherichia coli isolates from different retail meats in the United States, 2002 to 2008. Applied and Environmental Microbiology J., 1701-1707.

Zhao, S., White, D.G., Friedman, S.L., Glenn, A., Blickenstaff, K., Ayers, S.L., Abbott, J.W., Hall-Robinson, E., McDermott, P.F. 2008. Antimicrobial resistance in Salmonella enterica serovar Heidelberg isolates from retail meats, including poultry, from 2002 to 2006, Appl. Environ. Microbiol., 74(21): 6656-6662. 